Acta vet. scand. $1976,17,286-292$.

From the State Veterinary Laboratory for Northern Norway, Harstad and the National Veterinary Institute, Oslo, Norway.

\title{
A CASE OF AVIAN TUBERCULOSIS IN SHEEP
}

\author{
By \\ Knut Kummeneje and Finn H. Fodstad
}

\begin{abstract}
KUMMENEJE, KNUT and FINN H. FODSTAD: $A$ case of avian tuberculosis in sheep. Acta vet. scand. 1976, 17, 286-292. - A case of generalized avian tuberculosis in sheep is described. The case was somewhat unusual. No calcification and slight encapsulation together with scanty participation of epithelioid cells in the inflammations were typical features. The source of the infection, in an area where this disease is rare, is not known.
\end{abstract}

avian tuberculosis; sheep.

Tuberculosis is a rare disease in sheep. The reviews by Luke (1958) and Francis (1958) clearly showed the low incidence of the disease in most parts of the world. According to Francis, sheep are usually infected with either Mycobacterium bovis or Mycobacterium avium, while they are almost resistant to Mycobacterium tuberculosis. The lungs and associated lymph nodes are often involved in cases of tuberculosis in sheep. From details of 44 cases of tuberculosis in sheep given by Francis, evidence of generalization was present in $46 \%$ of the infections caused by Mycobacterium bovis, and in $64 \%$ of the infections caused by Mycobacterium avium. The lesions in sheep were very similar to those found in cattle, and they were often calcified and encapsulated.

\section{MATERIALS AND METHODS}

The material examined consisted of lung, heart, liver and spleen from a sheep. The animal was sacrificed by the owner after having been ill for about four months with progressive anaemia and loss of condition, increasing anorexia and fever. The animal belonged to a small farm with five dairy cows and six sheep. 
Samples for histology were fixed in $\mathbf{1 0} \%$ buffered formalin. Paraffin-embedded sections were stained with haematoxylineosin, Van-Gieson and with Ziehl-Neelsens staining method.

Bacteriological examinations were performed using bloodagar plates, L $\varnothing$ wenstein's, Petragnani's and Stonebrink's media.

Inoculation tests using guinea-pigs, rabbits and chickens were carried out.

\section{Gross morphology}

\section{RESULTS}

L i v e r. The size was normal. Greyish miliary nodules were visible beneath the capsule. The nodules were not easily seen on the cut surface. The texture was slightly coarser than normal. The hepatic lymph node was about normal size, but some small greyish nodules were visible on the cut surface.

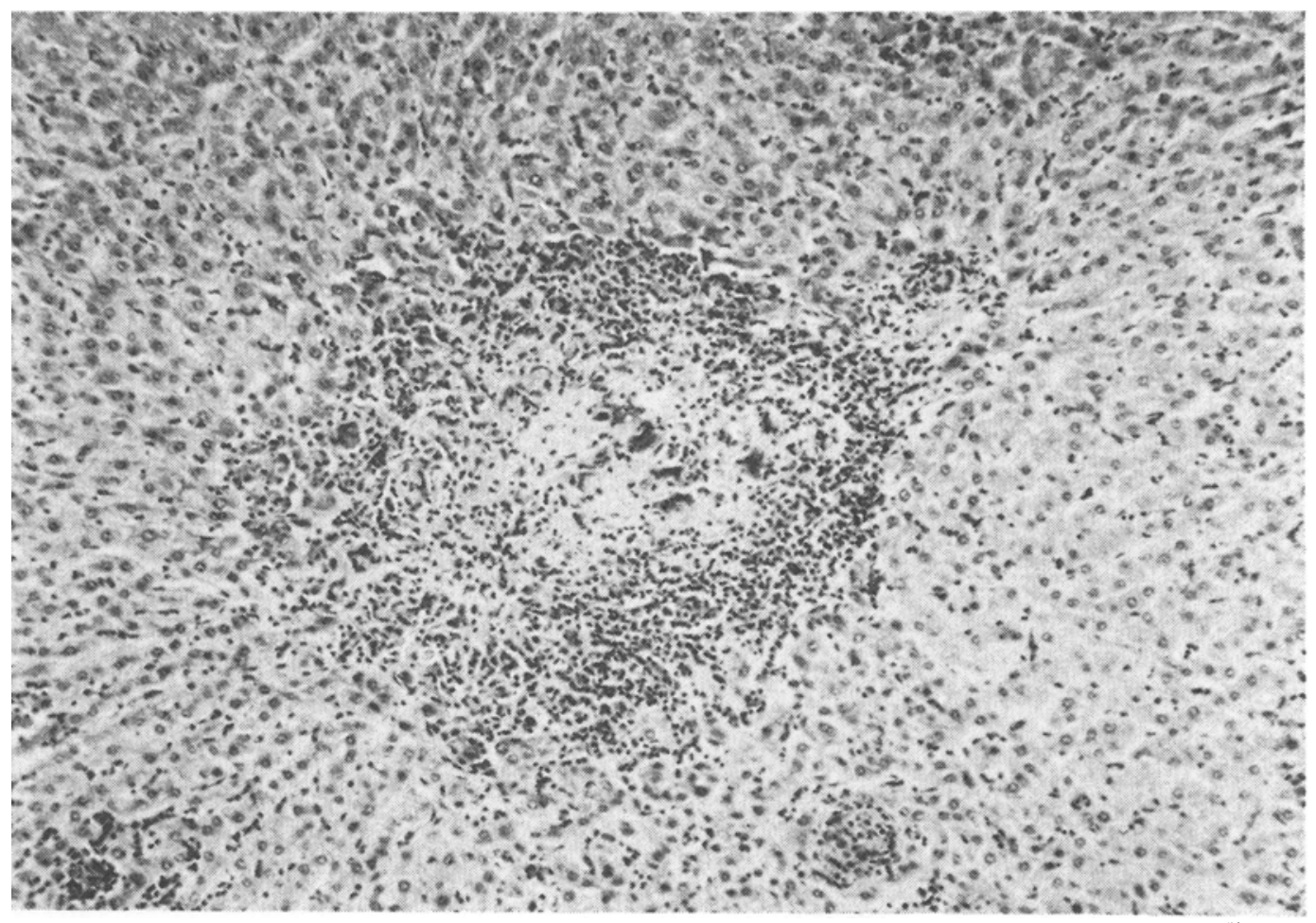

F i g u r e 1. Liver from infected sheep. Haematoxylin-Eosin. $125 \times$. Connective tissue and giant cells surrounded by small reticulo-endothelial cells and polymorphs can be seen in the central part. 


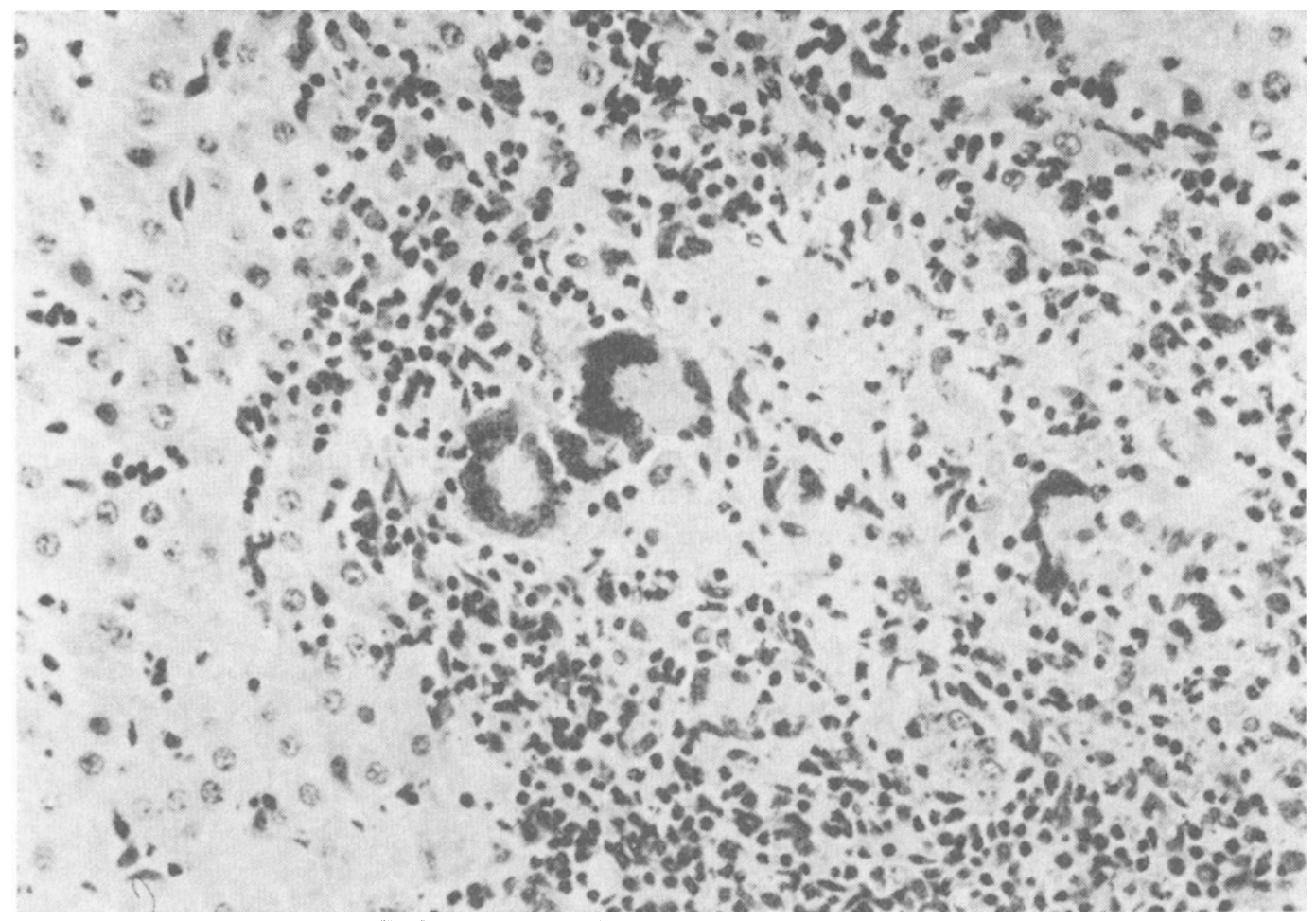

Figur e 2. Liver from infected sheep. Haematoxylin-Eosin. $312 \times$. Langhans giant cells surrounded by small reticulo-endothelial cells and polymorphs.

$\mathrm{S} p \mathrm{l}$ e e n. It was large and firm. The cut surface was greyish, and similar to mature connective tissue.

$\mathrm{L} \mathrm{u} \mathrm{n} \mathrm{g} \mathrm{s.} \mathrm{Mixtures} \mathrm{of} \mathrm{miliary} \mathrm{greyish} \mathrm{and} \mathrm{brownish} \mathrm{nodules}$ could be seen subpleurally and on the cut surface. The bronchial and mediastinal lymph nodes were increased in size.

\section{Histology}

Liver. Focal inflammatory changes with formation of miliary and submiliary nodules were observed. The smallest ones consisted of collections of a few small reticulo-endothelial cells, a few polymorphs, cellular debris and erythrocytes. The larger nodules were composed of small reticulo-endothelial cells, polymorphs, cellular debris and Langhans giant cells, while the central portion of the nodules consisted of mature connective tissue 


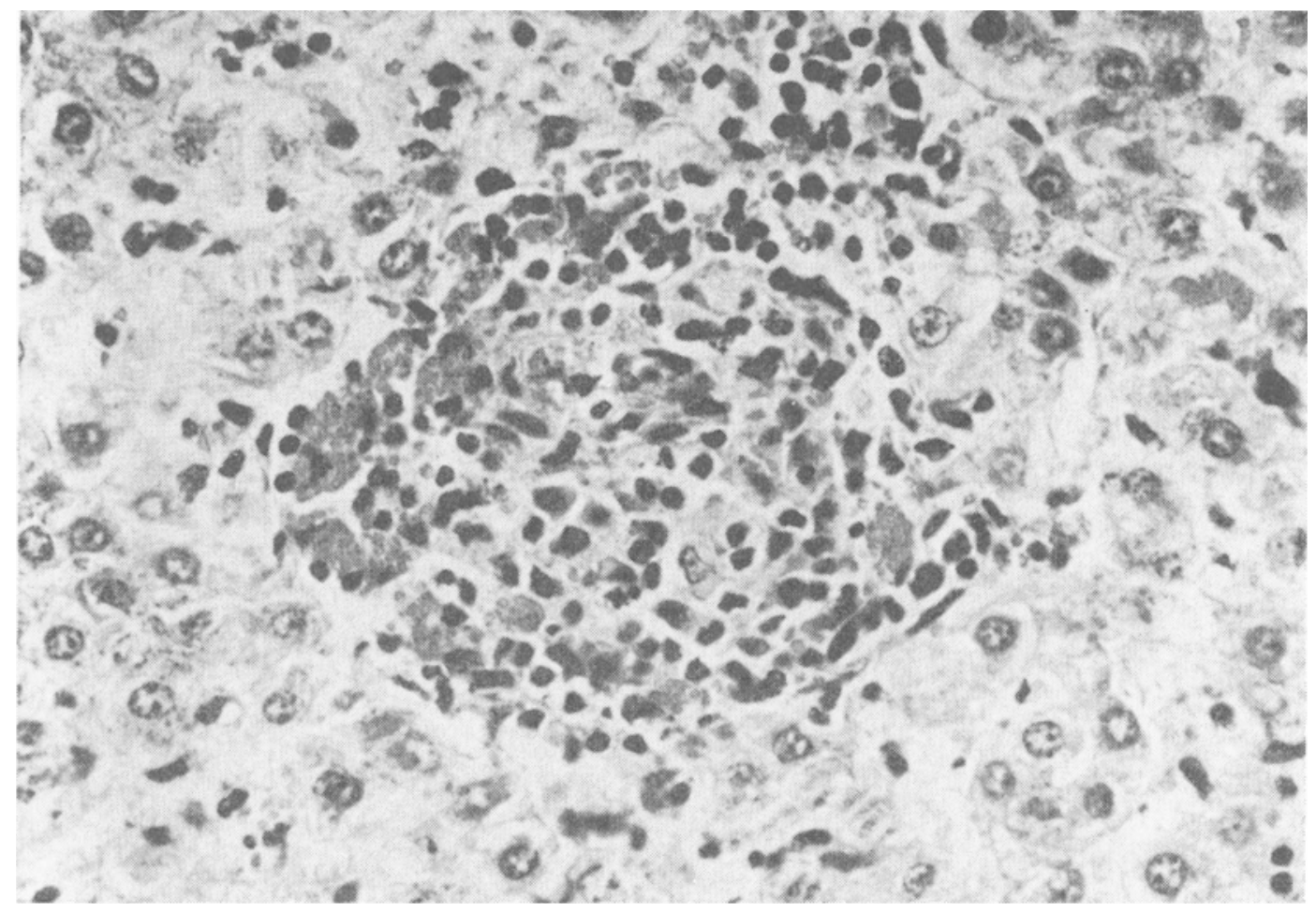

F i g u r e 3. Liver from infected sheep. Haematoxylin-Eosin. $500 \times$. Erythrocytes, necrotic material, polymorphs and small reticulo-endothelial cells.

in addition to the cell types mentioned above. Only very few reticulo-endothelial cells of the epitheloid variant could be identified in some lesions. The number of giant cells was unusually high and some of them were of the foreign body type. In the portal areas, extensive proliferations of small reticulo-endothelial cells mixed with a few polymorphs and plasma cells were observed together with proliferations of bile ducts. In the sinusoids, polymorphs and lymphocytes and hypertrophia of the fixed reticulo-endothelial cells were observed (Figs. 1, 2, 3).

$\mathrm{Hep}$ at i c ly m ph nod e. The occurrence of giant cells, most of them of Langhans type, was scattered. A few submiliary necrotic foci surrounded by giant cells were observed.

S p l e e n. Focal submiliary collections of inflammatory cells consisting of giant cells, mostly of Langhans type, some epi- 


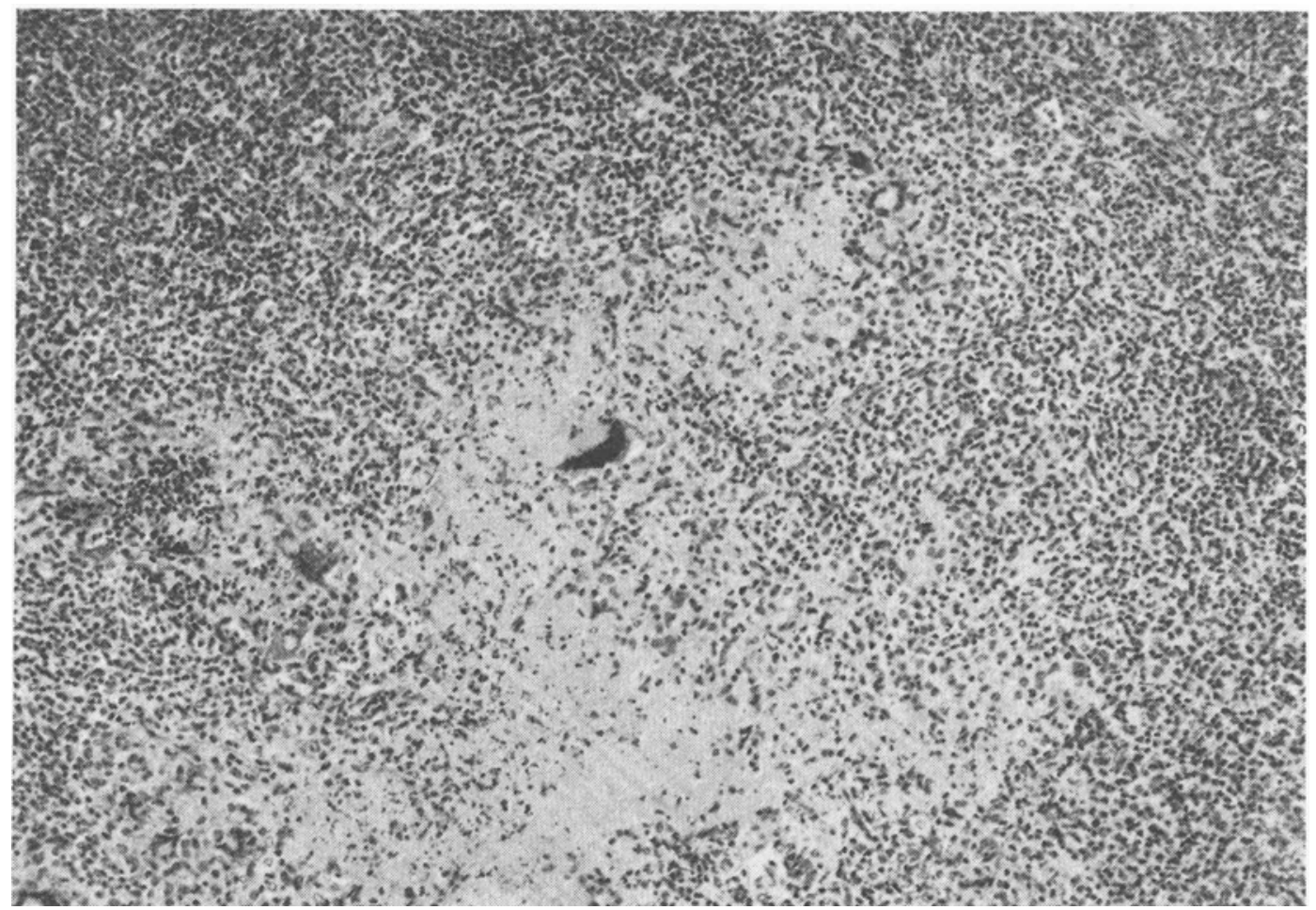

F i g u r e 4. Spleen from infected sheep. Haematoxylin-Eosin. $125 \times$. Scattered giant cells, polymorphs and necrosis.

thelioids and polymorphs, were seen. Also a few submiliary necrotic areas often surrounded by the above mentioned cell types, could be observed. The amount of connective tissue was increased (Fig. 4).

M y o c a r d i u m. Tuberculous processes were not observed.

L u n g. Miliary and submiliary inflammatory foci consisting of small reticulo-endothelial cells mixed with a few polymorphs, epithelioid cells and giant cells, mostly of the Langhans type, were found. In some foci, giant cells were lacking and in others there were small central necroses. The alveolar walls were thickened, mostly caused by infiltrating mononuclear cells (Fig. 5).

M ediastinal l y m ph node. Scattered occurrence of giant cells, mostly of Langhans type, was seen. A few submiliary necrotic foci were also observed. 


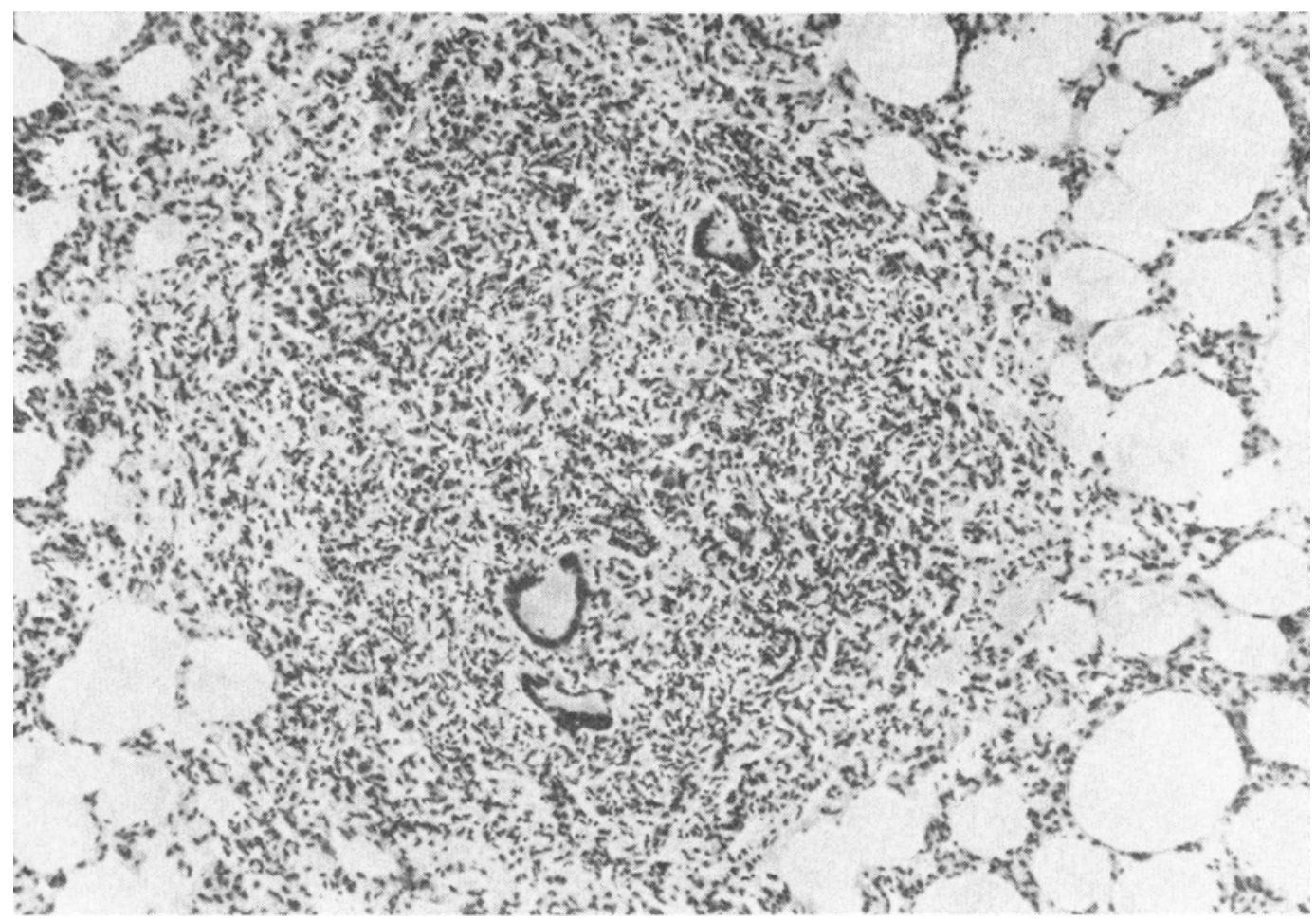

Figur e 5. Lung from infected sheep. Haematoxylin-Eosin. $125 \times$.

Langhans giant cells and polymorphs in a nodule consisting of small reticulo-endothelial cells.

\section{Bacteriology}

Growth on L $\varnothing$ wenstein's, Petragnani's and Stonebrink's media, the biochemical reactions with regard to niacin, acid phosphatase, reduction of nitrate, hydrolysis of Tween 80 , arylsulphatase and catalase activities at $37^{\circ} \mathrm{C}$ and $68^{\circ} \mathrm{C}$, together with inoculation tests in guinea-pigs, rabbits and chickens, resulted in the bacteriological diagnosis: Mycobacterium avium.

\section{DISCUSSION}

The case is one of generalized ovine tuberculosis caused by Mycobacterium avium. According to the literature, the lesions of tuberculosis in sheep are similar to those in cattle. They readily undergo encapsulation and calcification. In the present case no calcification and just slight encapsulation of the pro- 
cesses were observed. The liver lesions, in particular, also differed from the findings usually described in that epithelioid cells were rarely seen in the processes. The extensive proliferations of reticulo-endothelial cells and bile ducts in the portal areas were also prominent features.

Tuberculosis is very rare in this area and the source of the infection is not known.

None of the other animals on the farm was found to be infected, using tuberculin sensitivity tests.

\section{REFERENCES}

Francis, John: Tuberculosis in Animals and Man. A study in comparative pathology. Cassell and Company Limited. pp. 171175 , London 1958.

Luke, D.: Tuberculosis in the horse, pig, sheep and goat. Vet. Rec. 1958, 70, 529-536.

\section{SAMMENDRAG}

Et tilfelle av aviær tuberkulose hos sau.

Det er beskrevet et tilfelle av generalisert aviær tuberkulose hos sau $i$ et område hvor tuberkulose forekommer meget sjelden. Det makroskopiske og histologiske bildet var noe uvanlig. Forkalkninger ble ikke påvist og det var bare ubetydelig tendens til innkapsling av prosessene. Epithelioide celler var bare sparsomt tilstede, særlig i leveren, mens kjempeceller, særlig av Langhans type, var tilstede i stort antall. Infeksjonskilden er ikke kjent.

(Received April 12, 1976).

Reprints may be requested from: Finn H. Fodstad, The National Veterinary Institute, P.O. Box 8156, Oslo Dep., Oslo 1, Norway. 